\title{
EFFECTS OF DIETARY OXIDIZED FRYING OIL ON IMMUNE RESPONSES OF SPLEEN CELLS IN RATS
}

\author{
Bi-Fong Lin*, Ph.D., Ying-Jung Wu, Ph.D., Bor-Luen Chiang\#, M.D., Ph.D., \\ Jen-Fang Liu**, Ph.D. and Ching-Jang Huang, Ph.D.
}

Department of Agricultural Chemistry, College of Agriculture, and Graduate Institute of Clinical Medicine, College of Medicine\# ${ }^{\#}$ National Taiwan University, Taipei, Taiwan, Republic of China

\begin{abstract}
To investigate the effect of oxidized frying oil on immune responses of spleen cells, two groups of weanling Long-Evans male rats were respectively fed with diets containing either $15 \%$ fresh soybean oil (control) or $15 \%$ oxidized frying oil. After six weeks of feeding, immune responses including spontaneous and mitogen-stimulated proliferation, prostaglandin $\mathrm{E}_{2}$ (PGE2) production, levels of $\alpha$-tocopherol and thiobarbituric acid reactive substance (TBARS) of spleen cells were examined. The results showed that the ${ }^{3} \mathrm{H}$-thymidine incorporation in the absence of mitogen and in the presence of lipopolysaccharide (LPS, $5 \mu \mathrm{g} / \mathrm{ml}$ ) stimulation, was significantly higher $(p<0.05)$ in the oxidized frying oil group than in the controls. The PGE2 production of spleen cells from the oxidized frying oil group tended to be higher than that of the control group, but not significantly different. The decrease in $\alpha$-tocopherol level and increase in lipid peroxidation were not significant in the spleen cells from the oxidized frying oil group. The results indicated that dietary oxidized frying oil may increase spontaneous spleen cell proliferation and B cell activation, which may have significance in the development of altered immunological functions.

Copyitht 1997 Eleovier Science Inc.
\end{abstract}

KEY WORDS : Vitamin E, Frying oil, Prostaglandin E2, Mitogen response

\footnotetext{
*Corresponding Author : Dr. Bi-Fong Lin, Laboratory of Nutritional Chemistry, Department of Agricultural Chemistry, College of Agriculture, National Taiwan University. No.1, Sec. 4, Roosevelt Road, Taipei 10764, Taiwan

**Present address: School of Nutrition and Health Science, Taipei Medical College, Taipei, Taiwan.
} 


\section{INTRODUCTION}

Several studies have demonstrated that the quantity and quality of fat intake may play an important role in increasing the prevalence of immune abnormalities such as allergic and autoimmune diseases $(1,2)$. Most of the studies have focused on the effect of the amount and saturation of dietary fat on immune response $(3,4)$. Certain diets such as low fat and fish oil have been shown to modulate the disease course of autoimmune diseases and cancers $(5,6)$. In addition, increased dietary fat intake and a subsequent decreased cell-mediated immunity might contribute to recent increase incidence of oncogenesis such as breast cancer and colonorectal cancer (7). Although the mechanism how dietary fat affects immune response is still not well defined, several studies have suggested the involvement of a malfunction of macrophages and alterations in the production of proinflammatory mediators such as arachidonic acid, leukotriene, platelet activating factor, interleukin-1 (IL-1) and tumor necrosis factor- $\alpha$ (TNF- $\alpha$ ) $(8,9)$. It is possible that high polyunsaturated fat in the diet might also increase lipid peroxidation and alter metabolism of eicosanoids $(10,11)$.

Fried foods are an important fat source in the present-day industrialized dietary pattern, although the relative contribution is difficult to assess. The biological effects of lipid oxidation productions in foods has been reviewed recently $(12,13)$. Oarada et al (14) reported that oral intake of methyl linoleate hydroperoxides and the low molecular fraction isolated from autoxidized fatty acid (15) caused thymus necrosis. This can be prevented by simultaneous intake of $\mathrm{dl}-\alpha$-tocopherol (16). They also observed a significantly depressed ${ }^{3} \mathrm{H}$-thymidine incorporation into the thymocytes of mice orally dosed or long-term fed with autoxidized methyl linoleate (17). In vitro incubation of methyl linoleate hydroperoxide with human polymorphonuclear leukocytes suppressed phagocytic activity (18). However, the chemical composition of thermally oxidized frying oil is very different from an autoxidized lipid in that most of the hydroperoxides are decomposed at high frying temperatures, and high levels of polymers as well as other nonvolatile decomposition products are formed (19). Thermally oxidized frying oil is usually ingested with the fried foods in daily life.

We previously demonstrated increased liver microsomal enzyme activities as well as cytochrome P450 content (20), and decreased tissue vitamin E concentrations in rats fed with frying oil (21). Very few studies concerned the effect of dietary frying oil on immune response. To investigate the effect of frying oil on immune responses, two groups of rats were respectively fed with $15 \%$ frying oil or fresh oil diets. Mitogen response, prostaglandin E2 production, vitamin E and thiobarbituric acid reactive substance (TBARS) levels were measured to elucidate the effects of the oxidized frying oil on immune response of spleen cells. 


\section{METHODS AND MATERIAL}

Preparation of the oxidized frying oil and diets : The oxidized frying oil used was essentially from the same batch as those used in a previous study (21). Soybean oil purchased from a local supermarket was subjected to the following frying process: $9 \mathrm{~kg}$ soybean oil was poured into a cast iron wok and heated on a gas stove which was adjusted to maintain the oil temperature within $205 \pm 5^{\circ} \mathrm{C}$. Peeled potatoes were cut into sticks $(10 \times 1.5 \times 1.5 \mathrm{~cm})$ and fried in the oil. Every 30 $\mathrm{min}$ a batch of $100 \mathrm{~g}$ potato sticks was fried for $2.5 \sim 3 \mathrm{~min}$. The frying continued for six hr/day and was repeated successively for four days. The resultant oxidized frying oil was stored at $-20^{\circ} \mathrm{C}$ for the preparation of test diet. Another portion of the soybean oil was treated with active carbon (Sigma, St. Louis, MO) as described by Mohri et al.(22) to remove vitamin E. The vitamin Estripped soybean oil was also stored at $-20^{\circ} \mathrm{C}$ for the preparation of the fresh soybean oil control diet. The quality index of the test oil samples has been reported (21). The $15 \%$ fresh oil control diet and $15 \%$ oxidized frying oil diet were formulated according to the composition shown in Table 1.

Experimental animals : Four-week-old Long-Evans male rats were purchased from the Laboratory Animal Center, College of Medicine, National Taiwan University. They were housed and fed individually in stainless-steel wire cages. The animal room was maintained on a 12-hour light and 12-hour dark cycle and constant temperature $\left(25^{\circ} \mathrm{C} \pm 2{ }^{\circ} \mathrm{C}\right)$. Rats were randomly assigned to two groups with five rats in each group, and respectively fed the two diets. Tap water and diets were given freely.

TABLE 1

Composition of the Experimental Diets

\begin{tabular}{lcc}
\hline Ingredient ( $\mathrm{g} / \mathrm{kg}$ diet $)$ & Fresh oil diet & Oxidized frying oil diet \\
\hline Lactalbumin* & 200 & 200 \\
Fresh soybean oil (vitamin E stripped) & 150 & 0 \\
Oxidized frying oil & 0 & 150 \\
Corn starch & 577 & 577 \\
Cellulose & 30 & 30 \\
Choline & 3 & 3 \\
AIN-76 mineral mixture\# & 35 & 35 \\
AIN-76 vitamin mixture & 10 & 10 \\
\hline
\end{tabular}

\footnotetext{
*Ingredient sources : lactalbumin, choline, Sigma Chemical (St. Louis, MO); corn starch, Roquatte (Paris, France); $\alpha$-cellulose, J. Bettenmaier \& Söhne (Ellwangen-Holzmühle, Gcrmany). all-rac- $\alpha$ tocopheryl acetate, Hoffmann-La Roche Co.; Soybean oil, President Company (Tainan, Taiwan). \#American Institute of Nutrition (1977)
} 
Preparation of spleen cells : After six weeks of feeding, rats were sacrificed by carbon dioxide asphyxiation and spleens were isolated. Single spleen cell suspension was isolated by lysing red blood cells with tris-ammonia chloride buffer and was washed three times. The spleen cells were then suspended in RPMI 1640 medium supplemented with $10 \%$ fetal calf serum, $4 \mathrm{mM} \mathrm{L}$ glutamine, $25 \mathrm{mM}$ HEPES, $0.05 \mathrm{mM}$ 2-mercaptoethanol, $100 \mathrm{U} / \mathrm{ml}$ penicillin, $100 \mu \mathrm{g} / \mathrm{ml}$ streptomycin and $0.25 \mathrm{mg} / \mathrm{ml}$ amphotericin for further experiment. Two $\mathrm{ml}$ of cell suspension was frozen for $\alpha$-tocopherol and TBARS determination.

Mitogenic responses : $200 \mu \mathrm{l}$ single spleen cell suspensions were plated in 96 -well round bottom plates with the concentration of $1 \times 10^{6} \mathrm{cells} / \mathrm{ml}$ and cultured without mitogen or with one kind of mitogen at its optimal concentration chosen from preliminary test. The mitogens used in this study were LPS (lipopolysaccharide, $5 \mu \mathrm{g} / \mathrm{ml}$ ), PHA (phytohemagglutinin, $20 \mu \mathrm{g} / \mathrm{ml}$ ) or Con A (concanavalin $\mathrm{A}, 1 \mu \mathrm{g} / \mathrm{ml}$ ) in triplicate. The cells were incubated at $37{ }^{\circ} \mathrm{C}$ with $5 \% \mathrm{CO}_{2}$ for 48 hours and then $1 \mu \mathrm{Ci}$ of ${ }^{3} \mathrm{H}$-thymidine was added to each individual well. After additional 18 hours of incubation, the cells were harvested and radioactivity was measured with $\beta$-counter (Beckman LS $5000 \mathrm{CE}, \mathrm{UK})$.

Determination of PGE$_{2}$ production : To determine PGE2 produced by spleen cells, cells were cultured without or with one kind of mitogen at its optimal concentration chosen from preliminary test. The mitogens used in this study were LPS $(5 \mu \mathrm{g} / \mathrm{ml})$, PHA $(20 \mu \mathrm{g} / \mathrm{ml})$ or Con A (1 $\mu \mathrm{g} / \mathrm{ml}$ ) at the cell concentration of $1 \times 10^{6}$ cells $/ \mathrm{ml}$. After incubation at $37{ }^{\circ} \mathrm{C}$ with $5 \% \mathrm{CO}_{2}$ for $48 \mathrm{hr}$, the supernatant was collected by centrifugation. The level of $\mathrm{PGE}_{2}$ was determined with enzyme immunoassay kits (ELISA Technologies Co. KY).

The levels of vitamin $\mathbf{E}$ and TBARS in spleen cells : Frozen spleen cells were thawed and homogenized by a sonicator (Heat Systems Ultrasonics Inc. NY). Spleen cell vitamin E level was analyzed by reverse-phase HPLC as reported by Hatam and Kayden (23) with some modifications. For vitamin $\mathrm{E}$ determination, $1 \mathrm{ml}$ absolute ethanol (containing $1 \%$ pyrogallol) and $0.15 \mathrm{ml}$ of saturated $\mathrm{KOH}$ were added to $1 \mathrm{ml}$ of the cell homogenates in screw-capped tubes. Tubes were capped, vortexed and incubated in a $70^{\circ} \mathrm{C}$ water bath for $30 \mathrm{~min}$. After saponification, tubes were cooled in an ice bath, and then $1 \mathrm{ml}$ of distilled water and $2 \mathrm{ml}$ of $\mathrm{n}$-hexane were added. Tubes containing saponified homogenate were vortexed for $3 \mathrm{~min}$, and the organic layer was removed after separation. Solvent was removed and the residue solubilized in $0.1 \mathrm{ml}$ of methanol (containing 1 $\mathrm{mg} / \mathrm{ml} \mathrm{BHT}$ ) for HPLC analysis of vitamin E. For TBARS determination, $0.5 \mathrm{ml}$ cell homogenate was added with $0.05 \mathrm{ml} \mathrm{BHT} \mathrm{(0.2 \%} \mathrm{BHT} \mathrm{in} 95 \%$ alcohol) and $0.5 \mathrm{ml}$ TBA (2-thiobarbituric acid $0.4 \%$ in $0.2 \mathrm{~N} \mathrm{HCl}$ ). After an incubation at $50{ }^{\circ} \mathrm{C}$ for $1 \mathrm{hr}$, the mixtures were cooled and the TBAmalondialdehyde (MDA) adduct was extracted with $2 \mathrm{ml}$ isobutanol, and the fluorescence was measured with excitation at $515 \mathrm{~nm}$ and emission at $550 \mathrm{~nm}$. 1,1,3,3,-tetramethoxypropane (Sigma Chemical, St. Louis, MO) was used as the standard for the determination. The procedure was modified from one described by Tatum et al (24) 
Statistical analysis : Data were expressed as mean \pm SEM for each group except that food intake and body weight data were expressed as mean \pm SD. Randomized Complete Block Design were used to analyze the data of mitogen response and $\mathrm{PGE}_{2}$ production to exclude the day-to-day variation due to daily operation and measurements. The Student's t-test were used to analyze the data of vitamin $\mathrm{E}$ and TBARS measurement in this study.

\section{RESULTS}

Food intake and body weight : The food intake after six weeks of feeding was not significantly different between the fresh oil group and the oxidized frying oil group. The average food intake was $140.4 \pm 10.2 \mathrm{~g} /$ week for the fresh oil group and $128.2 \pm 15.9 \mathrm{~g} /$ week for the oxidized frying oil group. The body weight gain of the fresh oil group ( $49.13 \pm 4.67 \mathrm{~g} /$ week ) was slightly higher, but not significantly different, from that of the oxidized frying oil group (45.48 \pm $2.46 \mathrm{~g} /$ week).

Proliferation of the cultured spleen cell : The results of spontaneous and mitogen-stimulated proliferative response of splenic cells are summarized in Table 2. ${ }^{3} \mathrm{H}$-thymidine uptake in spontaneous and LPS-stimulated splenic cells were significantly higher in rats fed with oxidized frying oil compared to those of the fresh oil group $(p<0.05)$. In contrast, there was no difference in Con A or PHA-stimulated ${ }^{3} \mathrm{H}$-thymidine uptake between these two groups. However, the Con A mitogen stimulation index of the oxidized frying oil group was significantly lower than that of the fresh oil group $(\mathrm{p}<0.05)$.

\section{TABLE 2}

Mitogenic Response of Spleen Cells to PHA, Con A, and LPS from Rats Fed 15\% Fresh Oil or Oxidized Frying Oil Diets

\begin{tabular}{lcccc}
\hline Mitogens & \multicolumn{2}{c}{ Fresh oil diet } & Oxidized frying oil diet \\
\hline \multicolumn{4}{c}{ 3H-Thymidine incorporation, mean cpm \pm SEM\# } \\
Control & $1,413 \pm 150$ & & $2,838 \pm 204^{*}$ \\
PHA & $10,589 \pm 4,798$ & $(6.8 \pm 2.5)$ & $14,565 \pm 304$ & $(5.2 \pm 1.1)$ \\
Con A & $40,471 \pm 11,287$ & $(27.5 \pm 5.4)$ & $45.753 \pm 14,146$ & $(16.5 \pm 5.0)^{*}$ \\
LPS & $4,687 \pm 538$ & $(3.5 \pm 0.6)$ & $8.071 \pm 931^{*}$ & $(2.8 \pm 0.2)$
\end{tabular}

*Values were significantly different from those of rats fed $15 \%$ fresh oil diet statistically analyzed by Randomized Complete Block Design ( $<<0.05$ ).

\#Values shown in parentheses were for the stimulation index which is calculated from the cpm with mitogen divided by the cpm without mitogen (control). 
PGE2 production of the cultured spleen cell : The levels of $\mathrm{PGE}_{2}$ produced by cultured spleen cell are shown in Table 3. There was no significant difference in $\mathrm{PGE}_{2}$ production between the oxidized frying oil group and fresh oil group. Although the levels of PGE2 produced by LPSstimulated spleen cells of rats fed the frying oil diet tended to be higher, the difference was not statistically significant. The correlation between mitogen-stimulated proliferative responses and PGE2 production was shown in Table 4. There was a significant positive correlation between PHA stimulated proliferative response and PGE2 production in the fresh oil diet group but not in the oxidized frying oil group.

\section{TABLE 3}

Prostaglandin E2 Secretions of Spleen Cells from Rats Fed 15\% Fresh Oil or Oxidized Frying Oil Diets

\begin{tabular}{lcc}
\hline Mitogens & Fresh oil diet & Oxidized frying oil diet \\
\hline & \multicolumn{1}{c}{$\mathrm{pg} / 10^{6}$ cells $($ Mean \pm SEM) } \\
Control & $12.2 \pm 0.6$ & $13.0 \pm 1.7$ \\
PHA & $28.7 \pm 8.7$ & $31.2 \pm 6.1$ \\
Con A & $16.2 \pm 1.7$ & $16.5 \pm 1.8$ \\
LPS & $18.3 \pm 2.4$ & $44.6 \pm 21.4$ \\
\hline
\end{tabular}

\section{TABLE 4}

Correlation between Prostaglandin E2 Production and Proliferation Response in the Absence or Presence of Various Mitogens

\begin{tabular}{llcll}
\hline Mitogens & \multicolumn{2}{c}{ Fresh oil diet } & \multicolumn{2}{l}{ Oxidized frying oil diet } \\
\hline & & P value & & P value \\
Control & $r=-0.293 ;$ & $p=0.6320$ & $r=0.419 ;$ & $p=0.4825$ \\
PHA & $r=0.983 ;$ & $p=0.0026$ & $r=0.658 ;$ & $p=0.2279$ \\
Con A & $r=0.858 ;$ & $p=0.0632$ & $r=0.757 ;$ & $p=0.1384$ \\
LPS & $r=0.630 ;$ & $p=0.2542$ & $r=-0.261 ;$ & $p=0.6720$ \\
\hline
\end{tabular}

The $\mathrm{r}$ is abbreviated from regression coefficient. Regression coefficient was obtained by linear regression analysis of ${ }^{3} \mathrm{H}$-Thymidine incorporation (cpm/106 cells) and $\mathrm{PGE}_{2}$ value (pg/106 cells). $P$ value was analyzed by Microsoft Excel 5.0 program (Soft-Art Inc. CA). 
The levels of vitamin $E$ and TBARS in spleen cells : The results of vitamin $E$ and TBARS levels are shown in Table 5. There were no significance in these two parameters between the two groups.

\section{TABLE 5}

Level of Vitamin E and the Concentration of TBARS of Spleen Cells from Rats Fed 15\% Fresh Oil or Oxidized Frying Oil Diets*

\begin{tabular}{lcc}
\hline Group & Vitamin E (ng/106 cells) & TBARS (pmol/106 cells) \\
\hline Fresh oil & $1.54 \pm 0.31$ & $4.93 \pm 0.80$ \\
Oxidizing frying oil & $1.18 \pm 0.14$ & $6.03 \pm 1.43$ \\
\hline
\end{tabular}

*Values were Mean \pm SEM. Student's t-test were used to analyze the data.

TBARS : thiobarbituric acid reactive substance.

\section{DISCUSSION}

As reported previously (21), dietary frying oil did not affect food intake and body weight gain. It did not change the $\alpha$-tocopherol and TBARS levels in spleen cell pellets. This data agreed with previous result that the vitamin $\mathrm{E}$ and TBARS value were not significantly different between the oxidized frying oil and control groups when analyzed from the spleen homogenate (21). The data did not support the possibility that dietary oxidized frying oil may enhance lipid peroxidation of spleen cells. Moreover, the spleen weight: body weight ratio was not significantly different hetween the two groups (data not shown). As the ${ }^{3} \mathrm{H}$-thymidine incorporation of the cultured spleen cells in the frying oil group were not inferior to that of the control group, it appears that dietary oxidized frying oil did not result in severe damage in spleen.

In the absence of mitogen, the cultured spleen cells had low ${ }^{3} \mathrm{H}$-thymidine incorporation indicating very low level of proliferation. This low level of proliferation could be considered as an endogeneously derived potential, which mainly originated from the regulation of spleen cells in vivo by cytokine or mediators. In this study, the spleen cells of rats fed the oxidized frying oil diet showed significantly higher ${ }^{3} \mathrm{H}$-thymidine incorporation than that of the control group. Higher spontaneous proliferative response of the spleen cells from rats fed oxidized frying oil diet implied an altered regulation by cytokine and/or mediators in the body of this group of rats.

It has been demonstrated that high levels of dietary fat can increase the responses of lymphocytes and the numbers of plaque-forming cells in response to B cell mitogens such as LPS 
(25). Our data showed an increased LPS-stimulated proliferative response of splenic cells of rats fed with the frying oil diet compared to that of the fresh oil control group. However, there was no difference in proliferative responses to PHA and Con A-stimulated splenic cells between these two groups. Con A and PHA are mitogens specific to T cells, in contrast to LPS being specific to $B$ cells and macrophage. The data suggested that B cells were probably affected more significantly by dietary oxidized frying oil than $\mathrm{T}$ cells. It might be speculated that either the responsive cells from frying oil group were more sensitive to LPS stimulation or that there were more responsive cells among the spleen cell population that may be activated by LPS stimulation. Whichever the case may bc, it appears that dietary oxidized frying oil could affect the development of B cells. As the development of immune cells is mainly regulated by cytokines and/or mediators, the result again implied an alteration in the regulation by cytokine and /or mediators in the oxidized frying oil fed rats. This still needs to be further clarified.

Our data indicated that there is a positive correlation between $\mathrm{PGE}_{2}$ secretion and $\mathrm{T}$ cell mitogen-stimulated proliferative responses in rats fed with fresh oil. In contrast, no such correlation was noted between PGE2 level and LPS-stimulated response. It is possible that cytokines such as interferon- $\gamma$ (IFN- $\gamma$ ) and interleukin- 2 (IL-2) secreted by activated $T$ cells was responsible for the activation of macrophages in secreting $\mathrm{PGE}_{2}$. For the rats fed the oxidized frying oil diet, the correlation between proliferation and $\mathrm{PGE}_{2}$ production was not significant in $\mathrm{T}$ cell mitogen stimulated splenic cell culture. If the correlation observed in the fresh oil group arised from the regulation of macrophage $\mathrm{PGE}_{2}$ production by activated $\mathrm{T}$ cell through cytokines or other mediators, the absence of correlation implied that this regulation might be deviated in the oxidized frying oil group. Whether the relationship between $T$ cell proliferation and macrophage activation was affected by oxidized frying oil still needs to be investigated.

It has been documented that prostaglandin E2 could inhibit cell-mediated immunity (26). Recent studies showed PGE2 might increase cytoplasmic cyclic AMP and favor subsequent type $2 \mathrm{~T}$ helper cell $\left(\mathrm{TH}_{2}\right)$ development (27). Cytokines such as IL-2 and IFN- $\gamma$ secreted by type $1 \mathrm{~T}$ helper cell $\left(\mathrm{TH}_{1}\right)$ cells are important for cell-mediated immunity. In contrast, IL-4 and IL-10 produced by $\mathrm{TH}_{2}$ could inhibit the function and development of $\mathrm{TH}_{1}$. Imbalance between $\mathrm{TH}_{1}$ and $\mathrm{TH}_{2}$ has been found to play an important role in the pathogenesis of allergic disease, autoimmune disease and acquired immunodeficiency syndrome (AIDS) (28 31). In addition, decreased $\mathrm{TH}_{1}$-related function might also result in defected immune responses to tumor cells (32).

There has been a rapid increase in prevalence of certain immunological diseases such as allergic diseases and autoimmune diseases most recently $(33,34)$. This trend has been connected to the change of our living environments such as air pollution or dietary habit change. Increased intake of dietary fat was noted and suggested to play an important role in the increased prevalence of certain diseases such as tumors, allergic diseases and autoimmune diseases $(2,6)$. Several mechanisms have 
been proposed to explain the effect of dietary fat on immune responses, however, there is no definite conclusion. Dietary fat might affect immune response by changing the metabolism of inflammatory mediators such as prostaglandins, interleukin-1 and TNF- $\alpha(35,36)$.

In conclusion, the results of the present study showed that dietary frying oil did influence immune responses such as increased spontaneous proliferation and LPS-stimulated proliferative response. The correlation between $\mathrm{T}$ cell proliferation and $\mathrm{PGE}_{2}$ production was noted in the fresh oil diet group, but not in the oxidized frying oil diet group. Further study is needed to clarify the role of cytokines and/or mediators in these deviations. As fried foods are a significant constituent of high fat diets, the effect of oxidized frying oil is noteworthy in assessing the influence of a high fat diet.

\section{ACKNOWLEDGEMENTS}

This study was supported by a grant from the National Science Council of the Republic of China; NSC 83-0409-B-002-008.

\section{REEERENCES}

1. Erickson KL, Adams DA, McNeil CJ. Dietary lipid modulation of immune responsiveness. Lipids 1983; 18: 468-474.

2. Erickson KL, Hubbard NE. Dietary fat and tumor metastasis. Nutr Rev 1990; 48: 6-14.

3. Lin B-F, Huang C-C, Chiang B-L, Jeng S-J. Dietary fat influences la antigen expression, cytokines and prostaglandin E2 production of immune cells in autoimmune-prone NZBXNZW F1 mice. Brit J Nutr 1996 75: 711-722.

4. Fernandes G, Venkatraman JT. Role of omega-3 fatty acids in health and disease. Nutr Res 1993; 13 (suppl 1); S19-S45.

5. Erickson KL. Dietary fat modulation of immune response. Int J Immunopharmacol 1986; 8; 529 543. 
6. Fernandes G. Dietary lipids and risk of autoimmune disease. Clin Immunol Immunopathol 1994; 72: 193-197.

7. Thomas IK, Erickson KL. Lipid modulation of mammary tumor cell cytolysis: direct influence of dietary fats on the effector component of cell-mediated cytotoxicity. J Natl Cancer Inst 1985; 74: 675-680.

8. Sperling RI, Robin J-L, Kylander KA, Lee TH, Lewis RA, Austen KF. The effects of n-3 polyunsaturated fatty acids on the generation of platelet-activating factor-activating by human monocytes. J Immunol 1987; 139: 4186-4191.

9. Endres S, Ghorbani R, Kelley VE, Georgilis K, Lonnemann G, van der Meer JWM, Cannon JG, Rogers TS, Klempner MS, Weber PC, Schaffer EJ, Wolff SM, Dinarello CA. The effect of dietary supplementation with $\mathbf{n}-3$ polyunsaturated fatty acids on the synthesis of interleukin-1 and tumor necrosis factor by mononuclear cells. N Engl J Med 1989; 320: 265-271.

10. Kelley VE, Ferretti A, Izui S, Strom TB. A fish oil diet rich in eicosapentaenoic aid reduces cyclooxygenase metabolites, and suppresses lupus in MRL-lpr mice. J. Immunol. 1985; 134: 1914-1919.

11. Kinsella JE, Broughton KS, Whelan JW. Dietary unsaturated fatty acids: interactions and possible needs in relation to eicosanoid synthesis. J Nutr Biochem 1990; 1: 123- 139.

12. Kubow, S. Routes of formation and toxic consequences of lipid oxidation products in foods . Free Radical Biol Med 1992, 12: 63-81.

13. Kubow, S. Lipid oxidation products in food and atherogenesis. Nutr Rev 1993, 51: 33-40.

14. Oarada M, Ito E, Terao K, Miyazawa T, Fujimoto K, Kaneda T. The effect of dietary lipid hydroperoxide on lymphoid tissue in mice. Biochem Biophys Acta 1988a, 960: 229-235.

15. Oarada M, Ito E, Miyazawa T, Fujimoto K, Ito E, Terao K, Kaneda T. Degeneration of lymphoid tissues in mice with the oral intake of low molecular weight compounds formed during oil autoxidation. Agric Biol Chem 1988b, 52: 2101-2102.

16. Oarada M, Ito E, Yoshida L, Ito E, Terao K, Miyazawa T, Fujimoto K, Kaneda T. Simultaneous intake of tocopherol and autoxidized oils reduces the lymphocytic damage by dietary autoxidized oils. Agric Biol Chem 1990, 54: 1323-1324. 
17. Oarada M, Majima T, Miyazawa T, Fujimoto K, Kaneda T. The effect of dietary autoxidized oils on immunocompetent cells in mice. Biochem Biophys Acta 1989, 1012: 156-160.

18. Oarada M, Kurita N, Miyaji M, Terao K. Depression of phagocytic activity of human polymorphonuclear leukocytes by methyl linoleate hydroperoxides. J Nutr Sci Vitaminol 1991. 37: 625-628.

19. Chang S, Peterson RJ, Ho C-T. Chemical reactions involved in the deep-fat frying of foods. J Amer Oil Chem Soc 1978, 55: 718-727.

20. Huang C-J, Cheung N-S, Lu V-R. Effects of deteriorated frying oil and dietary protein levels on liver microsomal enzymes in rats. JAOCS 1988; 65: 1796-1803.

21. Liu J-F, Huang C-J. Tissue $\alpha$-tocopherol retention in male rats is compromised by feeding diets containing oxidized frying oil. J Nutr 1995; 125: 3071-3080.

22. Mohri K, Dohmoto C, Ikesu H, Igarasshi O. A simple elimination method of vitamin E from vegetable and fish oils for the preparation of vitamin E deficient diet. J Jpn Soc Nutr Food Sci 1983; 36: 122-124 (in Japanese).

23. Hatam HJ, Kayden HJ. A high-performance liquid chromatographic method for the determination of tocopherol in plasma and cellular elements of the blood. J Lipid Res 1979; 20: 639-645.

24. Tatum VL, Changchit, Chow CK. Measurement of malondialdehyde by high performance liquid chromatography with fluorescence detection. Lipids 1990; 25: 226-229.

25. Morrow WJW, Ohashi Y, Hall J, Pribnow J, Hirose S, Shirai T, Levy JA. Dietary fat and immune function in (NZBxNZW) F1 mice. J Immunol 1985; 135: 3857-3863.

26. Phipps RP, Stein SH, Roper RL. A new view of prostaglandin E regulation of the immune response. Immunol Today 1991; 12: 349-351.

27. Betz M, Fox BS. Prostaglandin E2 inhibits production of Th1 lymphokines but not of Th2 lymphokines. J Immunol 1991; 146: 108-113.

28. Clerici M, Hakim FT, Venzon DJ, Blatt S, Hendrix CW, Wynn TA, Shearer GM, Changes in interleukin- 2 and interleukin-4 production in asymptomatic, human immunodeficiency virusseropositive individuals. J Clin Invest 1993; 91: 759-765. 
29. Clerici M, Shearer GM. The Th1-Th2 hypothesis of HIV infection: new insights. Immunol Today 1994; 15: 575-581.

30. Lin L-C, Chen Y-C, Chou C-C, Hsieh K-H, Chiang B-L Dysregulation of T helper cell in autoimmune prone NZB x NZW F1 mice. Scand J Immunol 1995; 42: 466-472.

31. Romagnani S. Regulation and deregulation of human IgE synthesis. Immunol Today 1990; 11: 316-321.

32. Zou JP, Yamamoto N, Fujii T, Takenaka H, Kobayashi M, Herrmann SH, Wolf SF, Fujiwara H, Hamaoka T. Systemic administration of rIL-12 induces complete tumor regression and protective immunity: response is correlated with a striking reversal of suppressed IFN- $\boldsymbol{\gamma}$ production by anti-tumor T cells. Int Immunol 7: 1135-1145.

33. Chiang CC, Phinney SD, Halpern GM, Gershwin ME. Asthma mortality: another opinion-is it a matter of life and ... bread ? J. Asthma 1993,30: 93-103.

34. Homsy J, Morrow WJW, Levy JA. Nutrition and autoimmunity: a review. Clin. Exp. Immunol. 1986, 65: 473-488.

35. Hubbard NE, Somers SD, Erickson KL. Effect of dietary fish oil on development and selected functions of murine inflammatory macrophages. J Leuko Biol 1991; 49: 592-598.

36. Watanabe S, Onozaki K, Yamamoto S, Okuyama H. Regulation by dietary essential fatty acid balance of tumor necrosis factor production in mouse macrophages. J Leuko Biol 1993; 53: 151-156.

Accepted for publication December 20, 1996. 